\title{
Determination of Soil Strength Using 2D Geoelectric Methods and Direct Shear Test (Case Study in Istana Tidar Regency Housing - Jember)
}

\author{
Nurul Priyantari ${ }^{1}$, Supriyadi $^{2, *}$, Devi Putri Sulistiani ${ }^{3}$ and Winda Aprita Mayasari ${ }^{4}$ \\ ${ }^{1}$ Departemen of Physics, Natural Science Faculty, Jember of University \\ Jl. Kalimantan 25 Jember East Java \\ ${ }^{2}$ Departemen of Physics, Natural Science Faculty, Jember of University \\ Jl. Kalimantan 25 Jember East Java \\ ${ }^{3}$ Departemen of Physics, Natural Science Faculty, Jember of University \\ Jl. Kalimantan 25 Jember East Java \\ ${ }^{4}$ Departemen of Physics, Natural Science Faculty, Jember of University \\ Jl. Kalimantan 25 Jember East Java \\ ${ }^{*}$ Corresponding author's email : supriyadii [AT] unej.ac.id
}

\begin{abstract}
D geoelectrical resitivity measurement and direct shear test has been conducted to determine soil type and soil strength on land settlement Istana Tidar Regency housing, Jember. Resistivity measurement is conducted at two line that have latitude 08.10'102" - 08.10'108” $S$, 113.43'404" - 113.43'408" E (line 1) dan $08.10^{\prime} 102$ " - 08.10'108” S, 113.43'410”-113.43'414” E (line 2). Soil specimen were taken at 3 point, 2 point at line 1 and 1 point at line 2 . Based on result of $2 D$ geoelectrical resistivity measurement and direct shear test, this location was dominated by clay, silt and sandy silt are included in the type of cohesive soils. Soil strength of this type is capable to support light bulding contruction one or two floors.
\end{abstract}

Keywords - geoelectrical resistivity, direct shear test, soil type, soil strength

\section{INTRODUCTION}

Soil has an important role to plan the construction of a civilian building, its function is to proponent the foundation of the building (Hardiyatmo, 2012). As load-bearing of a building, soil often have movement especially on soft soil. Soft soil is soil which mostly consists of smallest particles such as clay or silt. Soil movement problems occur due to various factors, there are topography, geography, morphology, geologic structures, soil seepage and areas of earthquake potential. Therefore, before construct a civilian building requires knowledge of basic properties of soil in order to support load of building thereon. the basic properties of soil should know that physical properties and shear strength. The Factors are affecting the shear strength is the type of soil (cohesive and non-cohesive) and the water saturation level in cohesive soil. Soil cohesive is mostly composed of small grains which have a low shear strength. The shear strength of cohesive soil is determined from the grade of its cohesion. Examples of cohesive soil is clay, silt loam, sandy loam and silt. Noncohesive soil is soil that contains a lot of coarse grains that do not have a bond between the grains. Non-cohesive soil is appropriate material to support load-bearing of building because it is easily compacted and has a high shear strength. Examples of non-cohesive soil are sand, gravel, and rock (Hardiyatmo, 2010).

Geoelectric methods can be used to map subsurface structures. Geoelectric methods is a geophysical methods used to study the properties of current in subsurface. Basics principle of geoelectrical resistivity method is record electrical current of the earth itself or through injection of DC (Direct Current) into the earth. Rohim, et al (2010) use geoelectrical resistivity method to determine the structure of the soil. Permana and Sopyan (2013) has also conducted research on the determination of soils type by using geoelectrical resistivity method. Electrods configuration frequently used in this methos is Wenner (Figure 1). 


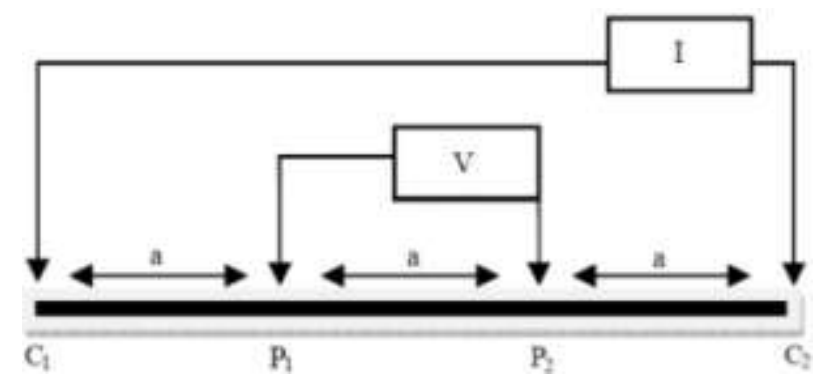

Figure 1. Wenner electrode configuration (Source: Loke, 1999)

Current and potential electrodes placed symmetrically to the point of sounding. The distance between the current electrodes three times the distance of the potential electrode. In Wenner configuration, four electrode i.e $\mathrm{C}_{1}, \mathrm{P}_{1}, \mathrm{P}_{2}$, and $\mathrm{C}_{2}$ with the same space totally moved at a fixed distance. Geometry factor in this method is $2 \pi \mathrm{a}$. Resistivity values of various types of soil shown in Table 1

Table 1 . Resistivity value for soils

\begin{tabular}{lc}
\multicolumn{1}{c}{ Type of soils } & Resistivity( $\mathbf{\Omega m})$ \\
\hline Clay : very wet and moist & $<1.5$ \\
Clayey soils : wet to moist & $1.5-3.0$ \\
Silty clay and silty soils : wet to moist & $3.0-15$ \\
Silty and sandy soils : moist to dry & $15-150$ \\
Bedrock : well fractured to slightly fractured with moist soil filled crack & $150-300$ \\
Sand and gravel with silt & \pm 300 \\
Bedrock: slight fractured with dry soil filled cracks & $300-2.400$ \\
Bedrock : massive and hard & $>2.400$ \\
\hline
\end{tabular}

Source : Hunt, Roy E.1984

One methods that are well suited for shear strength test is direct shear test. Direct shear test has been conducted by Nugroho (2011) in a mixture of clay-sand soils. In direct shear test, the normal stress $\sigma$ is obtained from the normal force $F_{n}$

$$
\sigma=\frac{F_{n}}{A}
$$

While the value of shear stress contrary to shear movement can be calculated as (Endah, 1985).

$$
\tau=\frac{F_{g}}{A}
$$

Graph of normal stress versus shear stress will produce a regression equation to obtain the value of soil cohesion $(c)$ and the friction angle in the soil $(\Phi)$ suitable to the theory of Mohr-Coloumb

$$
\tau=c+\sigma \operatorname{tg} \phi
$$

Annotation:

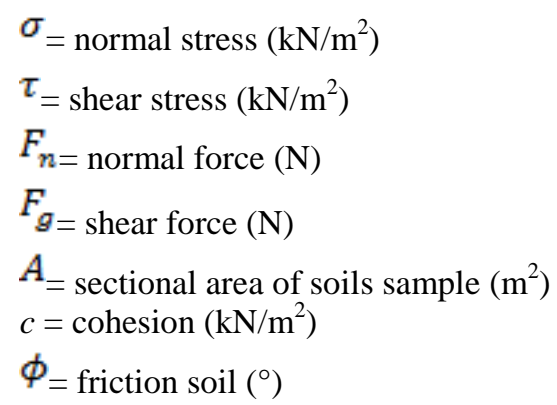


Based on the value of cohesion $(c)$ and friction angle $(\Phi)$ which obtained from direct shear tests, can be determined the type of soil. Value cohesion $(c)$ can be used to determine the classification of cohesive and non-cohesive soil (Muntohar, 2009). Where as for the value of the friction angle $(\Phi)$, soil type refere to Table 2.

Table 2. Values friction angle $(\Phi)$ for some types of soil

\begin{tabular}{lll}
\hline \multirow{2}{*}{ Soil type } & \multicolumn{2}{l}{ Friction angle $\Phi\left(^{\circ}\right)$} \\
\cline { 2 - 3 } & Loose & Dense \\
\hline Well-graded sand (angular grains) & $32-36$ & $35-45$ \\
sand (angular grains, subangular) & $30-34$ & $34-40$ \\
sand beach (round grains) & $28-32$ & $32-38$ \\
crushed gravel & $36-40$ & $40-50$ \\
Gravel on the cliff & $34-38$ & $38-42$ \\
Silty sands & $26-35$ & $30-36$ \\
Inorganic silt & $26-35$ & $30-35$ \\
Clay & $20-25$ & $20-25$ \\
\hline
\end{tabular}

Source: Bowles, J. E, 1984.

Based on above description, the goal of this research is to know the type of soil in Istana Tidar Housing Sumbersari Subdistrict Jember Regency. Geoelectric method is used to get an description of subsurface structure based resistivity values, which will be correlated with the type of soil. The result of geoelectric method is used to determine the points of soil sampling to be tested in the laboratory using direct shear test to get the value of cohesion and friction angle. The results of this research are expected to provide information on soil types in Istana Tidar Regency Housing so it can be a reference for development planning.

\section{METHODS}

\section{Geoelectric Methods}

The basics principle of the Wenner configuration in geoelectrical mapping method is: four electrode i.e $\mathrm{C}_{1}, \mathrm{P}_{1}, \mathrm{P}_{2}$, and $\mathrm{C}_{2}$ with the same spacing as a whole moved at a fixed distance. The Spacing depends on the depth of the subsurface layer to be mapped. Wenner configuration has advantages and disadvantages. the advantage of Wenner configuration is great spaced of potential electrode so that it does not require sensitive equipment. While the disadvantages is all the electrodes must be moved for each reading on the resistivity (Burger, 2006). If the spacing between the electrodes is a, then:

$$
r_{1}=r_{4}=a \text { and } r_{2}=r_{3}=2 a
$$

Thus, the potential difference at the point $\mathrm{P}_{1}$ and $\mathrm{P}_{2}$ are

so that

$$
\begin{aligned}
& \Delta V=\left(\frac{I \rho}{2 \pi}\right)\left\{\left(\frac{1}{a}-\frac{1}{2 a}\right)-\left(\frac{1}{2 a}-\frac{1}{a}\right)\right\} \\
& \Delta V=\frac{I \rho}{2 \pi}\left(\frac{1}{a}\right)
\end{aligned}
$$

$$
\rho_{a}=K \frac{\Delta V}{I}
$$

where $K=2 \pi a$ ( geometry factor of Wenner configuration)

\section{Direct Shear Test}

Direct shear test apparatus is consist of a metal box which containing a soil specimen to be tested. The box is divided into two sides in the horizontal direction. Soil specimen were used formed into a circular or square cross-section. Soil specimen size generally used is about 3-4 inch2 (1935.48 - 2580.64 mm2) cross section and a height of 1 inch (25.4 mm). The normal force in soil specimen obtained by placing a dead weight on top of the soil specimen. The dead weight can cause pressure on the soil specimen up to 150 Psi $(1034.2 \mathrm{kN} / \mathrm{m} 2)$. The shear force applied to push the sides top of the box until a shear failure in soil (Endah, 1985). The diagram of a direct shear test apparatus can be seen in Figure 2.

Figure 2. A diagram of the direct shear test apparatus (Source: Endah, 1985)

\section{RESULTS AND DISCUSSION}

Data acquisition of 2D geoelectrical resistivity is conducted in the Istana Tidar Regency housing results soil 
resistivity values. Apparent resistivity obtained by multiplying that value by the geometry factor of Wenner configuration. Inversion of the apparent resistivity values result a $2 \mathrm{D}$ pseudosection of the subsurface resistivity distribution. Data acquisition is conducted on vacant land consists of two line and resistivity imagery shown in Figure 3 and Figure 4.

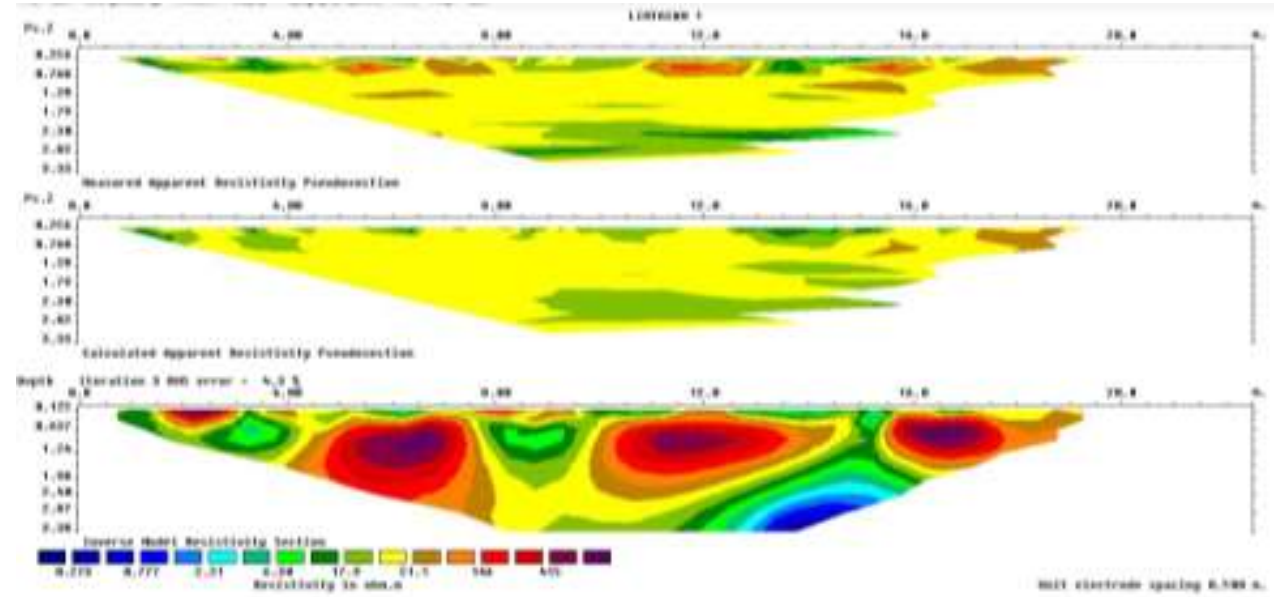

Figure 3. Results of pseudosection resistivity values on line 1

Line 1 is located at coordinates 0810'102"-0810'108" S and 11343'404"-11343'408" E, stretches from south to north. This line has a length of $20 \mathrm{~m}$ with the smallest electrode spacing of $0.5 \mathrm{~m}$. Based on Figure 3 , obtained a model subsurface resistivity layer with values ranging between $0.273 \Omega \mathrm{m}-415 \Omega \mathrm{m}$. This line is dominated by clay with gravel trapped between clay. Low resistivity shown by the blue color is interpreted as the ground water level at a depth of $2.5 \mathrm{~m}$.

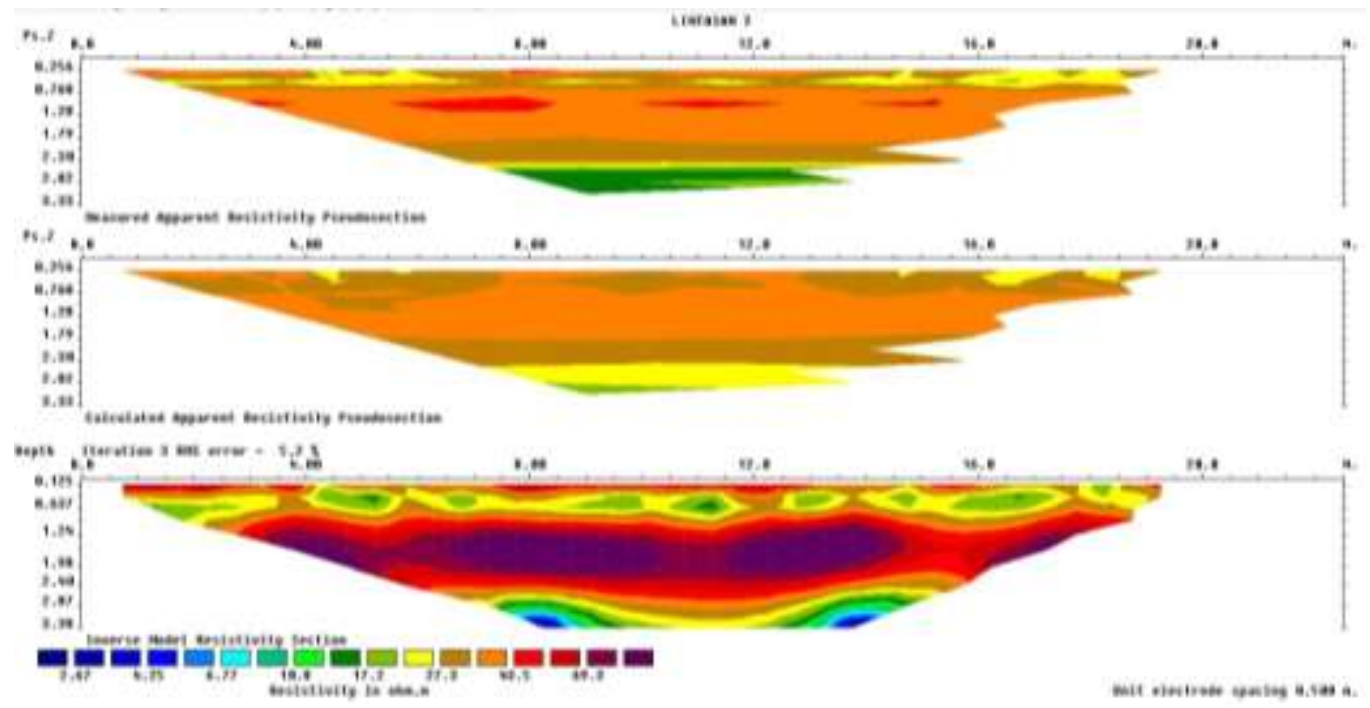

Figure 4. Results of pseudosection resistivity values on line 2

Line 2 is located at coordinates 0810'102"-0810'108" S and 11343'410 " 11343'414" E. This line parallel and stretches as far as $12 \mathrm{~m}$ from line 1 position with a length of $20 \mathrm{~m}$ and the smallest electrode spacing of $0.5 \mathrm{~m}$. Figure 4 shows that the variation of the resistivity of the subsurface structure of line 2 ranged between $2.67 \Omega \mathrm{m}-69.3 \Omega \mathrm{m}$. This line is thought to have the type of soil in the form of sand and clay.

Having obtained the model of the subsurface structure (Figure 3 and 4) performed soil sampling. There are three points we tested the soil specimen that point 1 is located in the line 1 with coordinates 810'105" S and 11343'404" E, Point 2 is located in the line 1 with coordinates 810'105" S and 11343'407" E, and Point 3 is located in the line 2 with coordinates 810'108 " S and 11343'410" E. The value of cohesion $(c)$ and friction angle $(\Phi)$ of three soil specimen shown in Table 3 .

Table 3. The value of cohesion $(c)$ and friction angle $(\Phi)$ of three soil specimen 


\begin{tabular}{|c|c|c|c|c|}
\hline $\begin{array}{c}\text { Soil } \\
\text { specimen }\end{array}$ & $\begin{array}{l}\text { Resistivity } \\
(\Omega m)\end{array}$ & $\begin{array}{l}\text { friction angle } \\
\left({ }^{\circ}\right)\end{array}$ & $\begin{array}{l}\text { cohesion } \\
\left(\mathrm{kg} / \mathrm{cm}^{2}\right)\end{array}$ & Soil type \\
\hline Point 1 & $17,9-51,1$ & 40 & 0,076 & $\begin{array}{l}\text { silty clay, silty soil wet mushy, silty soil, sand, sand } \\
\text { slightly graded. }\end{array}$ \\
\hline Point 2 & 6,3 & 25 & 0,080 & silty clay, silty soil wet mushy or silty sand. \\
\hline Point 3 & $10,8-17,2$ & 32 & 0,160 & $\begin{array}{l}\text { silty clay, silty soil wet mushy, clay, silt, silty sand, } \\
\text { sand slightly graded }\end{array}$ \\
\hline
\end{tabular}

In Table 3, soil specimen at point 1 has a value of friction angle $40^{\circ}$. Base on Table 2 , friction angle $40^{\circ}$ suspected soil type angular sand for dense soil and crushed gravel for loose soil. Point 2 have a value friction angle $25^{\circ}$, suspected to be soil type of clay. Whereas point 3 have a value friction angle $32^{\circ}$, suspected to be silty soil or silty sand. The test result of soil specimen from 3 point at depth 2-2.5 m using direct shear test, the soil type such as clay, silt, silty sand, and angular sand. Cohesion grade for the 3 point are small and the difference is quite small ie $0,076-0,160 \mathrm{~kg} / \mathrm{cm}^{2}$.

The results of geoelectric and direct shear tests showed that the location is dominated by clay, silt, silty sand and sandy soil, which means have a lot of fine grains that can be called a cohesive soil. Cohesive soil has a low shear strength, and has a carrying capacity of soil is very small. Cohesive soil can only be used for lightweight construction with a load that is not too large, such as building one floor to two floors.

\section{CONCLUTION}

Based on the measurements results of geoelectrical resitivity 2D Wenner configuration and direct shear tests, the soil type in Istana Tidar Regency Housing is dominated by clay, silt and silty sand. Both of these measurements can be complementary in which geoelectric measurements obtained the subsurface structure model while soil strength information obtained from direct shear tests.

\section{ACKNOWLEDGEMENT}

The authors would like to thank PT Teguh Karya Abadi as housing development of Istana Tidar Regency Housing that provide the location of research.

\section{REFERENCES}

[2] Bowles, J. E, Sifat-Sifat Fisis dan Geoteknis Tanah (Mekanika Tanah), Erlangga, Jakarta,1984.

[2] Burger, H. R, Jones Craig H dan Sheehan, Anne F, Applied Geophysics: Exploring the Shallow Subsurface, New York: WW Norton, 2006.

[2] Endah, N. Mekanika Tanah, Erlangga, Jakarta ,1985

[2] Hardiyatmo, H. C, Analisis dan Perancangan FONDASI bagian 1, Gadjah Mada University Press, Yogyakarta: 2010.

[2] Hardiyatmo, H.C, Mekanika Tanah 1 edisi 6, Gadjah Mada University Press, Yogyakarta, 2012.

[2] Loke, M.H. Electrical Imaging Surveys For Environmental And Enginering Studies. Malaysia. Penang, 1999.

[2] Montohar, A.S. Kuat Geser Tanah. Universitas Muhammadiyah, Yogyakarta:, 2009.

[2] Nugroho, S.A. Korelasi Parameter Kuat Geser Hasil Uji Geser Langsung dan Uji Triaksial pada campuran tanah lempung pasir., Jurusan Teknik Sipil Fakultas Teknik Universitas Riau, Riau, 2011.

[2] Permana, U dan Sopyan, A, Penentuan Jenis Tanah Berdasarkan Resistivitasnya Menggunakan Metode Geolistrik Tahanan Jenis. Jurusan Fisika Fakultas Sain dan Teknologi, Universitas Islam Negeri Bandung, . 2013

[2] Rohim, M. N., Subagio, H., dan Hidayah, N. Aplikasi Metode Geolistrik Sounding dengan Konfigurasi Pole-Pole Untuk Mengukur Resistivitas Bawah Permukaan Tanah dan Mengetahui Struktur Tanah. Malang: Universitas Negeri Malang, 2010.

[2] Hunt,Roy E., Geotechnical Engineering Investigation Manual. Mcgraw Hill, New York, Hunt,Roy E.1984 